\title{
TEACHERS' PERCEPTION OF PROFESSIONALISM IN COMPETENCY-BASED MEDICAL EDUCATION: ARE THERE ANY DIFFERENCES?
}

\author{
Rachmad Sarwo Bekti, Carissa Putri Irnanda, Setyawati Soeharto \\ Fakultas Kedokteran Universitas Brawijaya, Malang - INDONESIA
}

\begin{abstract}
Background: Medical professionalism learning for medical students in Faculty of Medicine of Universitas Brawijaya (FMUB) requires some clear indicators or values because of the Competency-based Curriculum (KBK). Those values can be arranged by looking for the local wisdom which is a group of visions or values from the lecturers' perceptions toward professionalism. This research was aimed to reveal the specific components of professionalism in FKUB perceived by faculty.
\end{abstract}

Method: This research was designed as a qualitative research by using semi-structured interviews of targeted subjects to gather the data constructs. The questions in interviews were designated to dig out the informer's perception in interpreting medical professionalism, based on their experiences, current visions, and hopes. Standardized qualitative analysis were applied to reveal the main themes of the responses.

Results: Themes which came up as the components of professionalism from 15 lecturers's perceptions were categorized as follow: attitude, clinical competence, and knowledge. Those main components were mentioned in National and International Standards related to professionalism, but not all the sub-components were mentioned. Spirituality and medical attire which became the sub-component of attitude were considered as specific construct of professionalism perceived by FKUB lecturers.

Conclusion: The concept of professionalism rooted on spirituality and expressed into proper attire in this research was expected to become a local wisdom of medical professionalism in Indonesia. It is advised that the results of this study can help the medical program administrator to develop instruments that nurture the professionalism development of students. Further research might be conducted by using different university context or by taking samples from larger faculty perspective with different specialization.

Keywords: local wisdom, lecturers' perceptions, medical professionalism, medicine

\begin{abstract}
ABSTRAK
Latar belakang: Pembelajaran profesionalisme membutuhkan deskripsi dan rujukan yang jelas karena terkait dengan tata nilai, budaya dan keyakinan. Dalam implementasi KBK (Kurikulum Berbasis Kompetensi) deskripsi ini menjadi esensial karena menjadi acuan dalam penyusunan pendekatan belajar dan terutama asesmen. Deskripsi kompetensi profesionalisme dalam Standar Kompetensi Dokter Indonesia dan beberapa kerangka kompetensi dokter internasional dianggap belum mewakili tata nilai lokal yang spesifik seperti pada tata nilai organisasi institusi. Penelitian ini dilakukan untuk menggali komponen profesionalisme yang khas di FKUB yang diharapkan dapat mengintegrasikan kebijakan pengelolaan institusi dengan pembelajaran profesionalisme.
\end{abstract}

contact: dr_rsbekti@ub.ac.id 
Metode: Penelitian dilakukan dengan metode kualitatif dengan melakukan wawancara semi terstruktur terhadap subyek penelitian. Pertanyaan-pertanyaan yang diajukan mengarah pada persepsi informan (dosen) dalam memaknai profesionalisme dokter, yang ditinjau dari pengalaman diri, pandangan saat ini, serta harapan para dosen.

Hasil: Didapatkan 15 orang informan yang bersedia untuk dilakukan wawancara dan didapatkan 22 tema profesionalisme. Tema-tema ini kemudian dikonsepkan menjadi menjadi 3 tema utama yang meliputi sikap/ perilaku (attitude), kompetensi klinis, dan pengetahuan. Ketiga tema utama/deskriptor yang didapatkan memiliki keterkaitan dengan deskriptor SKDI dan Standar Internasional yang terkait profesionalisme, dan beberapa sub tema yang tidak secara eksplisit ada di dalam dokumen rujukan. Sub tema khas yang tidak tercantum pada Standar Internasional tetapi tercantum pada Standar Nasional adalah spiritualitas, sedangkan yang tidak tercantum pada keduanya adalah deskriptor penampilan.

Kesimpulan: Konsep profesionalisme yang berakar pada spiritualitas dan diwujudkan dalam penampilan yang santun ternyata menjadi deskriptor khas di FKUB. Hasil penelitian ini diharapkan dapat berkontribusi terhadap perumusan konsep profesionalisme berbasis ke-Indonesia-an, khususnya dalam kontek pendidikan dokter.

Kata kunci: kearifan lokal, persepsi dosen, profesionalisme dokter

\section{PENDAHULUAN}

Sesuai dengan salah satu dari tujuh area kompetensi dalam Standar Kompetensi Dokter Indonesia (SKDI) yang dikeluarkan oleh Konsil Kedokteran Indonesia, yaitu 'Profesionalitas yang Luhur', maka seorang dokter harus mampu melaksanakan praktik kedokteran yang profesional sesuai dengan nilai dan prinsip ke-Tuhan-an, moral luhur, etika, disiplin, hukum, dan sosial budaya. ${ }^{1}$ Kompetensi ini perlu ditanamkan sejak menjadi mahasiswa kedokteran., dengan harapan, saat sudah benar-benar terjun ke masyarakat nanti para dokter muda sudah siap menjadi dokter yang profesional.

Walsh dan Abelson ${ }^{2}$ meramalkan bahwa jika kurikulum profesionalisme kedokteran masih belum juga dianggap penting, para dokter di tahun 2050 tidak akan lebih dari seorang teknisi. Hal ini menjadi mungkin karena ketika ilmu dan teknologi sudah sangat berkembang, dokter dan pasien akan lebih mempercayai mesin. Para dokter cenderung lebih sibuk mengamati hasil-hasil pemeriksaan laboratorium daripada mengamati secara langsung dan memikirkan yang terjadi pada pasiennya secara holistik, sehingga hubungan dokter-pasien akan semakin terabaikan ${ }^{2}$. Oleh karena itu, tidak hanya sekedar wacana, perhatian terhadap profesionalisme dan bagaimana mengajarkannya dalam pendidikan kedokteran merupakan agenda mendesak dan bahkan telah menjadi gerakan riil di dunia pendidikan kedokteran. ${ }^{3-5}$ Dengan dorongan SKDI, pembelajaran profesionalisme dalam pendidikan dokter di Indonesia diwujudkan dalam penerapan berbagai metode pembelajaran dan asesmen.

Sebagai realisasi SKDI dan tuntutan terhadap kebutuhan untuk menghasilkan dokter masa depan yang lebih professional, Fakultas Kedokteran Universitas Brawijaya (FKUB), mulai menerapkan pembelajaran profesionalisme secara eksplisit dan integratif di dalam kurikulum berbasis kompetensi (KBK).SalahsatunyadenganpenerapanMataKuliah Kompetensi (MKK) Dasar-Dasar Profesionalisme (DDP) dan Doctoring yang berjalan longitudinal selama pendidikan akademik mahasiswa (Semester I s/d VII). Dalam MKK ini, pembelajaran dilakukan dengan memberikan kesempatan bagi mahasiswa untuk sedini mungkin mengintegrasikan pengetahuan kognitif tentang ilmu kedokteran, keterampilan klinis dan profesionalisme dalam konteks klinis. Salah satu tujuan dari rangkaian MKK tersebut adalah agar mahasiswa mampu "Menunjukkan perilaku profesionalisme, belajar sepanjang hayat,menghargai pasien sebagai manusia 
budaya dan keselamatan orang lain sebagai esensi profesionalisme dokter". ${ }^{6}$

Mata Kuliah Kompetensi DDP dan Doctoring yang utamanya mengasah terbentuknya perilaku professional didisain sedemikian rupa sehingga mahasiswa tidak hanya memahami profesionalisme secara kognitif dengan berbagai tinjauan legal dan akademik, namun lebih dari itu, mahasiswa diharapkan juga dapat menerapkan nilai-nilai (value) professional dalam perilaku (behavior) keseharian sebagai tenaga medis professional yang diformulasikan dalam seperangkat capaian/tujuan belajar (intended learning outcome/output). Namun demikian, disadari bahwa deskripsi tujuan belajar tentang perilaku professional ini sebagian besar berasal dari literatur pendidikan kedokteran barat yang tidak diketahui apakah benar-benar sesuai dengan harapan dan tata nilai lokal Indonesia yang diyakini oleh para dosen atau tidak. Bahkan diketahui beberapa literatur rujukan merupakan produk dari penelitian di negara luar yang memiliki tata nilai dan budaya yang berbeda dengan kontek Indonesia. Bila merujuk pada definisi kompetensi dari Undang-undang RI No. 20 tahun 2003 tentang Sistem Pendidikan Nasional, lulusan hanya akan dianggap kompeten apabila dapat memenuhi ekspektasi dari masyarakat tempat ia menjalankan layanan kesehatan, baik masyarakat profesi, maupun masyarakat pengguna jasa layanan., ${ }^{1,7}$ Dengan demikian, pemahaman terhadap tata nilai dan kebijaksanaan lokal (local value $\mathcal{E}$ local wisdom) menjadi esensial bagi pembentukan profesionalisme yang menjadi salah satu komponen kompetensi dokter Indonesia. ${ }^{1}$

Dalam berbagai studi tentang pembelajaran perilaku professional, Birden et al ${ }^{8}$ menyebutkan bahwa peran keteladanan (role model) dosen menempati posisi esensial bagi pembentukan perilaku mahasiswa. ${ }^{8}$ Definisi yang dipahami dan dihayati dosen tentang profesionalisme dapat merupakan kurikulum tersembunyi yang justru lebih berpengaruh dalam capaian belajar tentang perilaku ini. Memahami definisi yang dihayati (persepsi) dosen terhadap profesionalisme akan memberikan kesesuaian antara ekspektasi institusi dan apa yang terjadi dalam interaksi dosen dan mahasiswa.
Dalam konteks ke-Indonesiaan, tidak banyak produk penelitian yang mengkaji tentang ekspektasi perilaku professional ini di lingkungan pendidikan dokter, apalagi yang dikaitkan dengan upaya untuk mengkaitkannya dengan kurikulum pendidikan dokter yang implementatif.

Oleh karena itu penelitian ini didisain dengan tujuan untuk menggali persepsi dosen terhadap profesionalisme dokter sebagai bagian dari upaya perbaikan kurikulum pendidikan dokter melalui eksplorasi persepsi dosen pendidikan dokter sebagai praktisi sekaligus sebagai akademisi terkait dengan apa yang penting dalam pembelajaran profesionalisme dokter.

Hasil dari penelitian ini diharapkan menjadi acuan dari penyusun kurikulum di institusi sekaligus sumbangan akademik terhadap kekayaan khazanah pengetahuan tentang profesionalisme dalam pendidikan kedokteran di Indonesia, khususnya dalam implementasi KBK. Penelitian ini sekaligus merupakan studi kasus dari eksplorasi terhadap

\section{METODE}

Penelitian ini merupakan penelitian kualitatif non-eksperimental, dengan menggunakan desain grounded theory. Penelitian dilakukan di Fakultas Kedokteran Universitas Brawijaya (FKUB) dengan sebelumnya mendapatkan izin dari otoritas fakultas dan telah memenuhi syarat laik etik (ethical clearance) dari komite etik FKUB.

Pengambilan data dilakukan dengan wawancara semi terstruktur kepada dosen yang ditentukan secara random dan convenience dan memenuhi persyaratan sebagai dosen yang senior (waktu mengajar lebih 10 tahun), terlibat dalam pembelajaran empati, profesionalisme dan/atau dosen yang terkenal memiliki perhatian dalam pembelajaran sikap dan profesionalisme dokter berdasarkan pengetahuan peneliti dari interaksi selama menjadi dosen, maupun dari informasi beberapa dosen yang lain. Setiap dosen dihubungi secara lisan dan dimintai persetujuan untuk menjadi informan untuk kemudian menandatangani inform consent kesediaan menjadi informan. ${ }^{9}$ 
Wawancara dilakukan oleh peneliti dengan menggunakan pedoman wawancara. Data yang didapatkan berupa hasil wawancara dan dibantu dengan hasil rekaman suara selama kegiatan wawancara. Hasil rekaman suara kemudian diubah menjadi bentuk transkrip wawancara. Koding terbuka dilakukan terhadap transkrip wawancara. Koding awal dilakukan oleh seorang peneliti, Hasil koding awal kemudian didiskusikan dengan peneliti lain untuk mendapatkan kesepakatan perspektif. Hasil koding kedua kemudian menjadi sumber untuk melakukan koding aksial (axial coding) yaitu melakukan pengelompokan koding kedalam kategori-kategori dan tema profesionalisme yang telah dikenal. ${ }^{10}$ Tema-tema yang didapatkan kemudian menjadi bahan analisis komparatif dengan teori, model serta konsep yang telah dikenal dalam literatur profesionalisme baik berupa artikel ilmiah maupu dokumen legal (seperti standar kompetensi nasional atau standar profesi). Dari hasil komparasi ini peneliti kemudian mencoba merumuskan konsep apa yang berbeda dan apa yang sama antara apa yang terjadi di lapangan (di FKUB) dengan teori-teori.

Akurasi dan kredibilitas data dicek dengan memberikan transkrip asli kepada informan (member checking). Informan diberi kesempatan untuk membaca transkrip apakah sesuai dengan maksud saat wawancara. ${ }^{11}$ Informan yang telah setuju memberikan tanda tangan di atas lembar transkrip yang diberikan sebagai tanda bahwa transkrip sesuai dengan maksud responden.

\section{HASIL DAN PEMBAHASAN}

Dari 70 orang dosen yang dihubungi yang memenuhi kriteria yang telah disebutkan diatas, ada 15 dosen yang terdiri dari 11 orang perempuan dan 4 orang laki-laki menyatakan kesediaan untuk menjadi informan. Meskipun tidak mewakili semua departemen, namun latar belakang informan cukup mewakili beberapa disiplin ilmu yang berbeda (Tabel 1).
Tabel 1. Karakteristik informan

\begin{tabular}{cll} 
Kode Informan & Jenis Kelamin & Disiplin Ilmu \\
\hline 01 & Perempuan & Faal \\
02 & Perempuan & Anatomi \\
03 & Perempuan & Parasitologi \\
04 & Laki-Laki & IPD \\
05 & Perempuan & Faal \\
06 & Perempuan & PA \\
07 & Laki-laki & IKM \\
08 & Laki-laki & PA \\
09 & Laki-laki & Obsgin \\
10 & Perempuan & Faal \\
11 & Perempuan & Radiologi \\
12 & Perempuan & Radiologi \\
13 & Perempuan & IKM \\
14 & Perempuan & Parasitologi \\
15 & Perempuan & Faal \\
\hline
\end{tabular}

Setelah menganalisis hasil transkrip wawancara, didapatkan 24 tema profesionalisme yang dianggap menjadi komponen profesionalisme dokter (Tabel 2).

Tabel 2. Tema-tema komponen profesionalisme dokter hasil analisa axial coding

\begin{tabular}{|c|c|}
\hline Tema Sentral & Tema Koding \\
\hline Attitude & $\begin{array}{l}\text { - Empati } \\
\text { - Altruistis } \\
\text { - Compassion } \\
\text { - Etis (Mengedepankan etika) } \\
\text { - Menghargai otonomi pasien } \\
\text { - Berdedikasi melayani pasien } \\
\text { - Komunikatif } \\
\text { - Tidak money oriented/tidak } \\
\text { materialistis } \\
\text { - Melihat pasien sebagai manusia } \\
\text { - Bertanggung jawab } \\
\text { - Disiplin } \\
\text { - Mampu bersosialisasi dan berjiwa } \\
\text { - Tosial } \\
\text { - Kolak membedakan pasien } \\
\text { - Kerjasama } \\
\text { - Medical attire (cara berpenampilan } \\
\text { \& berbusana) } \\
\text { - Spiritualitas }\end{array}$ \\
\hline $\begin{array}{l}\text { Kompetensi } \\
\text { Klinis }\end{array}$ & $\begin{array}{l}\text { - Dokter serba bisa } \\
\text { - Tanggap bencana } \\
\text { - Dokter komunitas } \\
\text { - Terampil } \\
\text { - Bertindak sesuai standar profesi }\end{array}$ \\
\hline Pengetahuan & $\begin{array}{l}\text { - Meningkatkan ilmu pengetahuan } \\
\text { - Inovatif }\end{array}$ \\
\hline
\end{tabular}


Tema-tema ini kemudian dianalisis kembali dengan cara mendiskusikan diantara peneliti hubungan dan keterkaitan, kesamaan dan perbedaanya. Setelah diskusi, tema-tema ini diyakini kemudian sebagai komponen utama profesionalisme yang dipersepsi oleh para informan. Sesuai dengan tujuan studi untuk melakukan rekonseptualisasi untuk kepentingan pembelajaran profesionalisme, maka tema-tema yang didapatkan kemudian dikategorikan menjadi tiga tema sentral (axial themes) yaitu: attitude, kompetensi klinis, dan pengetahuan. Tiap tema utama merupakan akumulasi dari beberapa komponen/tema lain yang lebih khusus/spesifik (Gambar 1). Pengelompokan tema-tema menjadi tiga tema sentral menjadi pembahasan pada artikel ini.

\section{Attitude}

Kata attitude dipilih karena makna asalnya yang kaya. Attitude sengaja tidak diterjemahkan ke dalam bahasa Indonesia untuk menghindari pengertian leksikal yang berbeda dengan maksud yang dikehendaki pada tulisan ini. Mengadopsi model Tripartite dari Rosenberg dan Hovland dengan model ABC (affective, behavioral and cognitive) yang kemudian disebut $\mathrm{CAB},{ }^{12,13}$ Attitude dimaknai sebagai suatu konstruksi kata yang didalamnya memuat tiga atribut/komponen, yaitu: afektif, behavioral (perilaku), dan cognitive (kognitif). Afektif menyatakan perasaan emosional terhadap suatu hal atau benda. Sementara, perilaku menyatakan reaksi seseorang atas perasaan emosional yang dihadapi. Kognitif adalah kepercayaan atau keyakinan seseorang terhadap suatu hal, yang berkaitan dengan afektif serta perilakunya. ${ }^{9}$

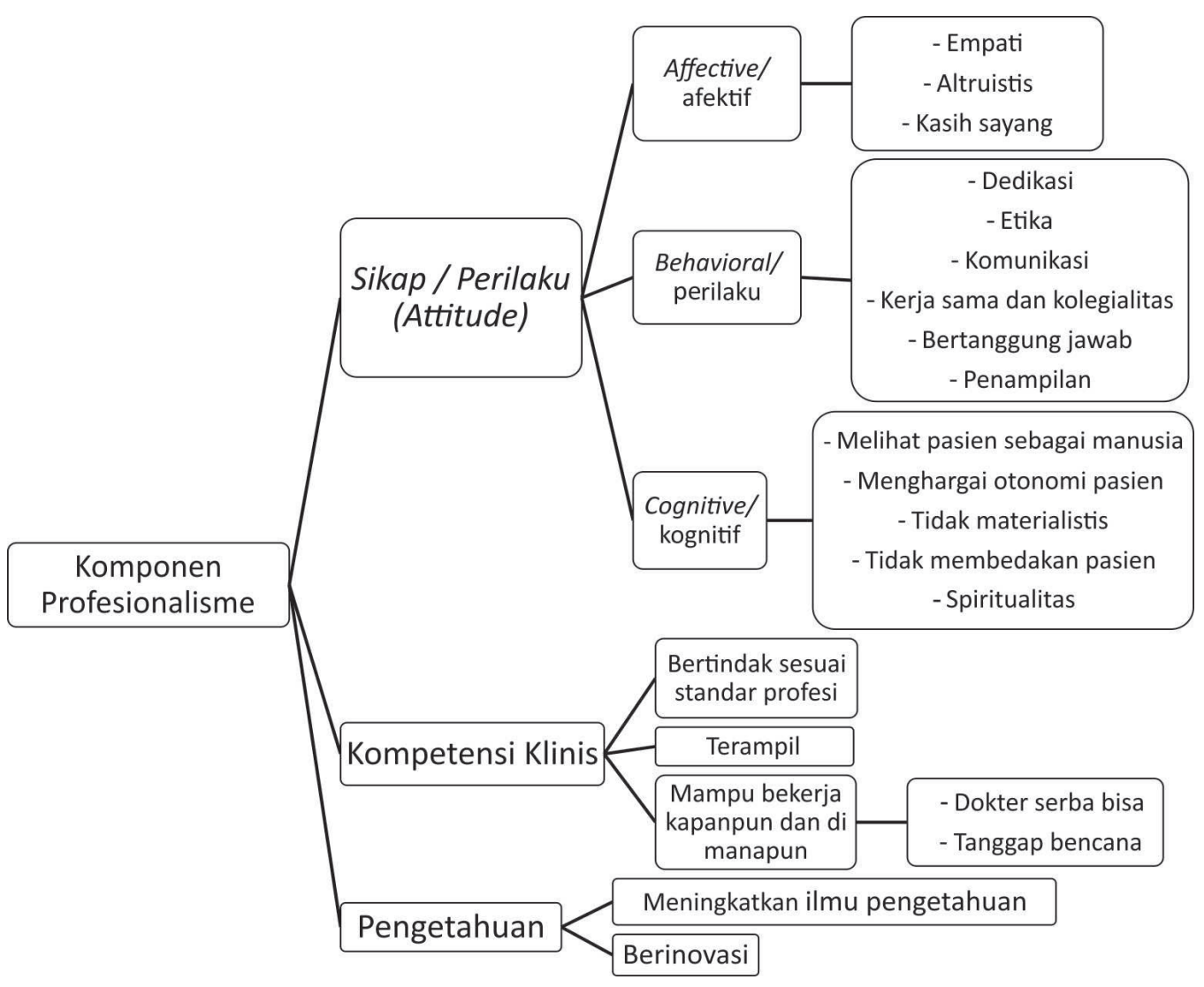

Gambar 1. Diagram konseptual komponen profesionalisme sebagai hasil analisis koding tema yang didapatkan dalam penelitian 
Hampir semua informan mengungkapkan bahwa pengertian profesionalisme utamanya bermuara pada kategori attitude ini. Menjadi seorang dokter diyakini perlu memiliki komponen profesionalisme yang masuk kategori attitude (baris pertama dari Tabel 2). Salah satu komponen penting profesionalisme adalah Empati. Empati adalah pengalaman emosional antara pengamat dan subyeknya. Dokter yang berempati adalah dokter yang dapat memahami pasiennya dengan baik, bahkan bisa merasakan hal yang dirasakan oleh pasiennya. Demi mencapai pelayanan kesehatan yang optimal, penting bagi para dokter untuk mendengarkan dan memahami pasien dengan empati dan respek. Dokter seharusnya memahami segala hal yang diinginkan, dibutuhkan, dan dikhawatirkan oleh pasien. ${ }^{14,15}$

"Pertama, seorang dokter itu harus bisa mengerti, artinya ada hubungan yang erat ya antara pasien dengan dokternya. Harus berempati, menjiwailah keadaan pasiennya itu." - W.D 10.

Selain itu, komponen afektif yang harus dimiliki seorang dokter adalah altruisme. Altruisme merupakan lawan kata dari egoisme. ${ }^{16}$ Sementara Steinberg mengungkapkan bahwa altruisme dalam klinis berarti sebuah sikap dan aksi yang bertujuan untuk meningkatkan kesejahteraan orang lain, tanpa mengharap adanya imbalan. ${ }^{17}$

“.... Jadi nomor satu harus ditanamkan rela berkorban, mementingkan orang lain, tidak mikir kita nanti jadi apa, sukses atau nggak. Artinya menomorduakan diri sendiri. Ya kelihatannya sih klise ya, tapi kalau kita udah punya jiwa seperti itu, yang lain akan mengikutinya, saya kira seperti itu." - WD.04.

Altruisme juga telah tergambar secara kultural dalam kehidupan kemahasiswaan, bahkan mahasiswa melalui organisasi mahasiswa telah secara proaktif menjadikan altruisme sebagai nilai dasar. Hal ini diyakini merupakan wujud adaptasi dari nilai-nilai yang diyakini dan tergambarkan dalam karakter yang menonjol dari alumni sebagai produk pendidikan.
"Saya tahu kan waktu saya mendampingi BEM dulu, mahasiswa itu punya ikon 'Be an altruistic leader', itu kan menurut saya - dan sekarang sudah banyak terbukti kan dengan adanya mas Gamal, dokter Rita, itu menurut saya sudah terbukti, bukan hanya jargon." - WD 07

Komponen selanjutnya dalam segi afektif adalah kasih sayang atau compassion. Dokter harus memiliki rasa kasih sayang terhadap pasiennya, sehingga pasien merasa nyaman. Rasa nyaman cukup penting dalam pelayanan kesehatan. Menurut penelitian, tingkat mortilitas pasien bedah jantung menurun pada pasien yang merasa nyaman. ${ }^{17}$

"Ruh seorang dokter itu altruism dan compassion, ya. Itu harus kelihatan. Jadi bagaimana dia punya compassion - rasa kasih sayang, dan altruism - rasa ingin menolong orang lain. Itu adalah, menurut saya, ruh dari professionalism." - WD 07

Bagian kedua dari attitude adalah perilaku atau behavioral. Perilaku seorang dokter yang profesional adalah berdedikasi. Hal ini tercantum dalam salah satu prinsip profesionalisme menurut Physician Charter. ${ }^{18}$ Dedikasi adalah pengorbanan tenaga, pikiran, dan waktu demi keberhasilan suatu usaha atau tujuan mulia, yang dalam konteks ini adalah keselamatan dan kesejahteraan pasien.

"Kita bertindak dan bekerja, tetap mengutamakan keselamatan pasien, kenyamanan pasien. Bagaimana pasien itu bisa tertangani secepat mungkin, se-efisien mungkin, se-ekonomis mungkin, dengan biaya semurah-murahnya dan optimal lah. Prinsip ekonomi. Tentu saja tidak menghilangkan dari segi keilmuan. Kita berusaha dengan teknik atau panduan-panduan terkini, ya. Jadi mengutamakan kepentingan pasien, keselamatan pasien, dengan tidak mengurangi kualitas, bisa dibilang begitu ya." - WD 04

Seorang dokter yang profesional harus siap bekerja sepanjang waktu demi kesejahteraan pasien. Menurut WD 02, waktu dokter sudah 'dibeli' oleh pasien, sehingga seorang dokter harus mampu mengupayakan yang terbaik bagi pasiennya. 
“... bahwa pasien itu ya bisa dikatakan kita itu sudah dibeli ya, maksudnya itu waktu kita, gitu, kompetensi kita itu sudah dibeli oleh pasien gitu, sehingga sudah selayaknya kita memberikan, menjawabnya itu dengan ... -jadi ya, yang dibeli maksudnya kita dibayar gitu, pasien itu berarti membayar kita, bos kita toh, berarti harusnya kita menjawabnya dengan profesional, jadi sangat penting." - WD 02

Dokter yang profesional juga harus mampu berdedikasidalam meningkatkan kualitas pelayanan. Komitmen ini bukan hanya dengan meningkatkan kompetensi klinis saja, melainkan dengan meningkatkan kolaborasi demi meningkatkan keselamatan pasien dan mengoptimalkan hasil pelayanan. ${ }^{18}$

"Karena kalau tidak berdedikasi, ya, enggak profesional itu." - WD 01

Selanjutnya, perilaku mendasar yang perlu ada dalam setiap dokter adalah etika. Kemampuan dan kompetensi harus didukung dengan etika yang baik. Relevan dengan Kode Etik Kedokteran Indonesia, sudah seharusnya dokter memegang teguh etika kedokteran, karena tanpa adanya etika maka profesi dokter tidak lagi layak disebut sebagai profesi yang luhur. ${ }^{19}$ Etika yang dimaksud tidak hanya terbatas pada etika terhadap pasien, tetapi juga etika terhadap sejawat, maupun profesi lain.

"Jadi seorang dokter selain dia itu punya kemampuan, kompeten, juga yang kedua adalah mempunyai etika." - WD 09

"Menjunjung tinggi etika. Etika pada pasien, maupun pada teman sejawat, ...... Jadi menjunjung tinggi etika, kepada siapapun deh." WD 06

Setelahmampumenjunjungtinggietikayangberlaku, seorang dokter juga harus mampu berkomunikasi dengan pasien. Lemahnya komunikasi antara dokter dan pasien akan berdampak dalam kesulitan dalam mendiagnosis dan menentukan terapi yang tepat, serta berdampak pada kepercayaan pasien. Seorang dokter harus mampu menjelaskan kepada pasien tentang penyakit dan segala tindakan yang akan dilakukan. Sebaliknya, pasien harus bisa terbuka terhadap dokter mengenai keluhannya.

"Dan once (sekali) lemah berkomunikasi, habis sudah semua. Communication, berkomunikasi yang tidak menyakitkan, gitu ya. Komunikasi kan banyak nih. Komunikasi inform consent, kadangkadang, "Sakit apa, bu?" Enggak usah pakai diperiksa juga-- ... ini, tetapi secara manusiawi dia kan butuh dipegang." - WD 01

Dalam meningkatkan pelayanan kesehatan diperlukan adanya kolaborasi antar tenaga kesehatan khususnya dokter. Kolaborasi membutuhkan kerja sama dan kolegialitas antar sejawat. Alumni dinilai telah menjunjung tinggi kerja sama dan kolegialitas sejak dulu, namun dinilai semakin memudar pada generasi-generasi baru. Dengan adanya kerja sama yang baik antar dokter, diharapkan kasus yang rumit akan dapat lebih mudah terselesaikan. Misalnya ada pasien yang memiliki penyakit yang kompleks, maka dibutuhkan kolaborasi dari multidisiplin ilmu.

"Dari tahun ke tahun, lulusan FKUB menunjukkan degradasi dalam hal kerja sama. Semakin tinggi jenjang pendidikan yang ditempuh, justru semakin individualistik, sehingga sebaiknya dari awal perkuliahan sudah ditanamkan rasa kerja sama dan tenggang rasa yang baik." - WD 03

"Dengan bekerja sebagai tim, akan tepat diagnosa, tepat pelaksanaan, karena dipikir oleh banyak kepala kan beda dengan cuma satu orang tok (saja) mutusi (memutuskan) ... (misalnya) diabetes mellitus udah ada komplikasinya jadi stroke, jadi (sakit) jantung, jadi apa. Nah harusnya kan itu kerja tim ya. Ahli penyakit dalam, konsulkan jantungnya ke spesialis jantung, kan demi pasien gitu lho orientasinya harusnya." - WD 06

"Yang diharapkan ada kerja sama tim, karena nanti pas jadi dokter nggak akan sendirian." - WD 11

Hal lain yang wajib dimiliki bagi seorang dokter adalah tanggung jawab. Seorang dokter harus mampu bertanggung jawab atas segala tindakan dan perkataannya. 
"Seorang yang profesional juga harus memiliki integritas tinggi sehingga accountable atau dapat dipercaya. Seluruh tindakan dan keputusannya harus bisa di-pertanggungjawabkan dan ada alasannya mengapa demikian." - WD 13

"Dokter yang profesional adalah dokter yang dapat mengemban amanah, tugas, dan kewenangannya dengan penuh tanggung jawab dan berkompeten." - WD 15

Selain itu, attitude seorang dokter secara perilaku dapat dilihat dari aspek yang tangible atau nyata terlihat. Seorang dokter yang profesional harus mampu berpenampilan dengan baik dan pantas. Dokter yang berpakaian formal dapat mempengaruhi tingkat kepercayaan pasien terhadap dokter, serta kepercayaan diri dokter tersebut. ${ }^{20}$

"Profesionalisme itu menurut saya yang pertama, justru ada yang terlihat dan tidak terlihat, yang tangible dan intangible. Yang tangible menurut saya medical attire, penampilan fisik dokter itu sudah masuk dalam ranah professionalism. Oleh karena itu banyak sekali jurnal-jurnal ilmiah yang mengungkapkan pentingnya seorang dokter memiliki medical attire yang baik. Contohnya dalam berpakaian, penampilan fisik-lah, packaging-nya. Itu kan sudah terlihat profesional, kan?" - WD 07

Bagian ketiga dari attitude adalah kognitif, yaitu keyakinan atau pemikiran seseorang terhadap suatu hal. Dimasukkan dalam kategori ini adalah melihat pasien sebagai manusia, menghargai otonomi pasien, tidak materialistis, tidak membedakan pasien dan spiritualitas. Manusia adalah makhluk yang unik. Dokter harus dapat melihat pasien sebagai seorang manusia seutuhnya, bukan sebagai angka atau obyek. Dengan melihat pasien seutuhnya, dokter diyakiti akan dapat menganalisis keluhan pasien serta segala faktor-faktor lain yang relevan terhadap penyakit tersebut. ${ }^{21,22}$

"Profesionalisme itu menurut saya dekat kaitannya dengan tadi melayani tadi, memenuhi kebutuhan pasien itu, apa mencakup, tidak hanya melihat pasien sebagai, apa ya, yang datang mengeluh suatu, satu kondisi gitu, tidak melihat penyakitnya, keluhannya, itu melihat pasien secara keseluruhan berarti dia sudah bisa profesional" - WD 02

Selain itu dokter harus mampu menghargai otonomi pasien. Dalam Physician Charter disebutkan bahwa dokter harus jujur terhadap pasien dan memberikan kesempatan pada pasien untuk membuat keputusan atas segala tindakan akan yang dilakukan kepadanya, namun otonomi tersebut dibatasi oleh etika dan standar yang berlaku. ${ }^{15}$ Menghargai otonomi pasien berarti dokter tidak bisa memaksakan kehendaknya, dan harus mengikutsertakan pasien dalam setiap pembuatan keputusan terapi.

"Yang kedua memperhatikan otonomi pasien berdasarkan hak-hak yang pasien punya dalam pelayanan medis." - WD 05

"Otonomi di dalam konteks yang disebut otonomi itu mampu untuk berkomunikasi secara terbuka dan terus menerus, ya, atau memberi ini. Kita kalau misalnya, aku tidak-- tidak bisa merawat pasien ini ya harus aku konsulkan gitu kan." WD 01

Meskipun sebagian percaya bahwa imbal balik materi tetap penting, namun mengingat bahwa profesi dokter adalah sebuah pengabdian, maka seorang dokter yang profesional haruslah meletakkan kesejahteraan pasien di atas kesejahteraan diri sendiri. Dokter harus fokus terhadap tujuan utamanya yaitu kepentingan pasien, dan setelah itu respek dan keuntungan finansial akan datang dengan sendirinya. ${ }^{23,24}$

"Kalau kamu tidak profesional, maka kamu akan hanya menghitung-hitung, "Uangku dapet berapa ya?" Sekarang ini dengan BPJS ini kalau yang dokter umum itu enak toh, dia enggak ngapangapain duitnya sejumlah kepala yang ada di kecamatan misalnya." - WD 01

"Jangan kayak bisnis, mergo sekolahe larang, engko narike larang (karena sekolahnya mahal, nanti narik uangnya mahal)." - WD10 
Segala tindakan atau terapi yang hendak diberikan kepada pasien harus disertai dengan pertimbangan cost-benefit, yaitu menimbang dari segi biaya dan keuntungan, baik terhadap pasien dari tingkat sosial menengah ke bawah hingga tingkat sosial tertinggi. Maka dari itu, dokter tidak boleh semerta-merta meminta biaya jasa yang lebih tinggi pada pasien dari kelas sosial yang tinggi. Dalam segi kualitas pelayanan pun harus disamaratakan. Seorang dokter harus mampu bersikap adil terhadap pasiennya.

"Kalau saya ya, untuk pasien itu jangan membedabedakan antara pasien yang nggak punya dan yang punya, menurut saya ya. Contoh kalau kamu sedang praktek, kemudian ada pasien datang bawa mobil bagus, kamu nariknya mahal daripada pasien yang naik becak. Nggak boleh membedakan seperti itu. Jadi, tidak boleh membeda-bedakan. Nggak boleh itu. Harus sama." - WD 10

Selain itu, dalam melakukan tindakan seorang dokter haruslah mempertimbangkan dari segi spiritualitas/religiusitas. Spiritualitas mengandung pengertian hubungan manusia dengan Tuhannya. ${ }^{16}$ Seorang dokter akan mampu bekerja dengan baik jika mengikuti aturan-aturan dalam agama atau kepercayaan yang diyakininya.

"Tapi hal lain yang perlu ditekankan adalah dokter harus memiliki attitude yang baik. Entah itu attitude kita ke atas, atau attitude kita ke pasien." - WD 05

"... karena saya sebagai orang muslim, jadilah dokter yang islami. Rangkaian aturan-aturan, halal haram, ya sesuai aturan yang islam mau, insya-Allah aman selamat." - WD 05

\section{Kompetensi Klinis}

Dokter yang kompeten adalah dokter yang mampu bertindak sesuai standar profesi yang berlaku, baik SKDI (Standar Kompetensi Dokter Indonesia), maupun standar profesi tiap-tiap spesialisasi.

"Jadi melakukan segala kegiatan dalam profesi dokternya dengan cara yang sesuai standar. ... Jadi sesuai dengan standar, dan etika yang berlaku." WD 06
"Profesionalisme adalah suatu kemampuan seseorang untuk melakukan suatu pekerjaan tertentu sesuai standar pekerjaan tersebut." - WD 12

Saat seorang dokter melakukan sesuatu sesuai standar yang ada, maka jika terjadi sesuatu pada pasiennya, dokter tersebut memiliki perlindungan hukum karena telah melakukannya sesuai indikasi dan sesuai standar profesi yang ada.

"Jadi itu menjadi dasar untuk hukum nanti, kalau misalnya terjadi tuntutan, ... ya sudah berarti nggak bisa dituntut. Sudah terlaksana sesuai standarnya. - WD 06

"Dengan bertindak sesuai standar, maka akan terlindungi secara hukum." - WD 14

Selain mampu bertindak sesuai standar, dokter harus mampu bertindak secara terampil. Terampil berarti cakap dalam mengerjakan tugas atau pekerjaan. Dokter profesional harus memiliki kemampuan clinical reasoning, clinical judgement, dan clinical skills yang baik.

"Dokter harus memiliki kemampuan clinical reasoning dan clinical judgement, serta clinical skill yang baik." - WD 07

"Profesionalisme berarti memiliki kompetensi di bidangnya. Kalau sebagai seorang dokter berarti harus memiliki di bidang skill kedokteran yang nantinya akan diuji di Ujian Kompetensi Dokter Indonesia (UKDI)." - WD 13

\section{Pengetahuan}

Profesi dokter adalah pembelajar seumur hidup. Dalam kedokteran, komitmen untuk terus belajar dengan keras selama menjalankan profesi merupakan bagian penting dalam profesionalisme dokter. ${ }^{25}$ Dalam ilmu kedokteran, setiap hari akan muncul penemuan baru, guideline atau pedoman baru, hingga teknologi kedokteran yang baru. Untuk menyikapinya, seorang dokter harus mau belajar dan mengembangkan pengetahuannya setiap harinya. 
“... profesionalisme dokter sangat sangat dibutuhkan. Yang pertama, harus sering mengupdate ilmu kedokteran untuk memberikan pelayanan terbaik." - WD 05

"Think global, bukan think local. bagaimana bisa maju kalau kita tidak baca lebih dulu? Selalu bacanya terlambat. Gimana? Apa yang kamu baca? ... malah sampai sini (seringnya hanya) catatan kuliah ...." - WD 09

"Pengetahuan kedokteran akan terus berkembang dan tidak pernah habis sehingga harus terus dipelajari." - WD 13

"Kita berusaha dengan teknik atau panduanpanduan terkini, ya." - WD 04

\section{Perbandingan Persepsi Informan, Standar Nasional, dan Standar Internasional Tentang Profesionalisme Dokter}

Peneliti berkeyakinan bahwa agar pembelajaran profesionalisme berjalan secara optimal, dalam KBK perlu disusun kerangka koseptual profesionalisme yang tidak hanya mengadopsi nilai-nilai yang diformulasikan secara top down, misalnya dengan mengadopsi SKDI secara taken for granted. Kerangka konseptual pembelajaran profesionalisme perlu disusun dengan cara mengintegrasikan nilainilai universal dari berbagai standar Internasional, nilai-nilai yang diarahkan oleh organisasi profesi serta peraturan perundangan dan juga menguatkan nilai-nilai luhur lokal yang dipandang telah mengantarkan alumni institusi menuju puncak kesuksesan profesi. Oleh karena ini tulisan ini juga membahas bagaimana keterkaitan konstruk/tema yang telah diformulasikan dengan berbagai standar yang dikenal dalam literatur nasional maupun internasional agar terbentuk kerangka konseptual yang optimal untuk pembelajaran KBK.

Dari kajian yang dilakukan, peneliti dapat melihat adanya kesamaan konsep dari 24 tema yang muncul dalam penelitian ini dengan berbagai standar nasional, utamanya SKDI dan Kode Etik Dokter Indonesia (KODEKI). SKDI mencakup beberapa kompetensi yang harus dimiliki seorang dokter. Sedangkan KODEKI mencakup etika yang harus dimiliki dan dilakukan oleh dokter. Merujuk pada teoripersepsi, Hojatet, al ${ }^{25}$ dan Cassam ${ }^{26}$ menguatkan bahwa persepsi manusia dalam memandang suatu obyek dibentuk oleh pengalaman dan pengetahuan. Dalam mempersepsikan sesuatu diperlukan peran pengetahuan dan pengalaman. Suatu obyek hanya dapat memberikan suatu persepsi bagi seseorang, jika orang tersebut memiliki pengetahuan sebelumnya dan jika obyek tersebut telah memunculkan pengalaman pada orang tersebut. ${ }^{25,26}$ Informan pada penelitian ini secara akademik semuanya memiliki gelar dokter, namun demikian mereka dapat dikategorikan sebagai dokter yang praktik maupun dokter yang tidak berpraktik. Persepsi para dosen FKUB yang berpraktik diduga terutama didapatkan selama berpraktik yang mendasarkan referensinya KODEKI. Sedangkan, pengetahuan para informan yang tidak berpraktik selain berasal dari KODEKI, ditengarai juga dapat berasal dari pemahaman terhadap SKDI (Standar Kompetensi Dokter Indonesia) yang merupakan referensi pencapaian sasaran belajar dalam proses pendidikan. Dari analisis didapatkan bahwa beberapa tema yang muncul dari wawancara dengan informan memiliki kesamaan yang kuat dengan pernyataan tertulis pada kedua standar nasional ini (lihat Tabel 3).

Dalam SKDI, terdapat 7 area kompetensi dokter yaitu: Profesionalitas yang luhur, mawas diri dan pengembangan diri, komunikasi efektif, pengelolaan informasi, landasan ilmiah ilmu kedokteran, keterampilan klinis, pengelolaan masalah kesehatan. Menurut SKDI, profesionalitas masuk ke dalam kompetensi yang harus dimiliki seorang dokter. Mawas diri dan pengembangan diri, komunikasi efektif, dan keterampilan klinis menjadi bagian dari kompetensi yang harus dimiliki oleh seorang dokter, sedangkan pada penelitian ini hal-hal tersebut merupakan bagian dari komponen profesionalisme dokter. Mawas diri dan pengembangan diri berkaitan dengan komponen 'Pengetahuan', komunikasi efektif berkaitan dengan komponen 'Komunikasi', dan keterampilan klinis masuk ke dalam komponen 'Kompetensi Klinis'. Kemudian area kompetensi profesionalitas yang luhur menurut SKDI artinya mampu melaksanakan praktik kedokteran yang profesional sesuai dengan nilai dan prinsip ke-Tuhan-an, moral luhur, 
etika, disiplin, hukum, dan sosial budaya. Dalam penelitian ini, hal tersebut memiliki kesamaan dengan komponen 'Spiritualitas' dan 'Etika'.'

Dalam KODEKI ${ }^{19}$ profesionalisme diatur sendiri dalam pasal 8 yang berbunyi:

"Seorang dokter wajib dalam setiap praktik medisnya, memberikan pelayanan secara berkompeten dengan kebebasan teknis dan moral sepenuhnya, disertai rasa kasih sayang (compassion) dan penghormatan atas martabat manusia."

Hal ini berkaitan dengan komponen 'Attitude', yang lebih spesifiknya yaitu komponen 'Kasih sayang' dan 'Melihat pasien sebagai manusia'. Selain itu, dalam pasal 2 KODEKI (Standar pelayanan kedokteran yang baik), seorang dokter wajib mengambil keputusan profesional secara independen dan sebelumnya harus dilakukan pemeriksaan dan penilaian terhadap pasien sesuai dengan standar pelayanan kedokteran yang diakui secara sah. Dalam pengambilan keputusan seorang dokter diharapkan menjunjung altruisme. Seorang dokter juga berkewajiban untuk menjamin terlayani pasien di manapun berada, siapapun dirinya, bagaimanapun situasi dan kondisi lingkungannya. Hal ini sesuai dengan komponen 'Bertindak sesuai standar profesi', 'Mampu bekerja kapanpun dan di manapun', 'Altruistis', dan 'Tidak membedakan pasien'. Kemudian, KODEKI pasal 18 (Menjunjung tinggi kesejawatan) yang berkaitan dengan komponen 'Kerja sama dan kolegialitas' serta pasal 21 (Perkembangan ilmu dan teknologi kedokteran) yang berkaitan dengan komponen 'Pengetahuan'. ${ }^{19}$

Meskipun persepsi informan diduga kuat telah dipengaruhi oleh SKDI dan KODEKI, namun ternyata masih banyak komponen profesionalisme yang dipersepsikan sendiri oleh para dosen, yang secara verbatim tidak ditemukan di dalam kedua standar tersebut. Merujuk pada konsep Community of Practice $^{27}$ dan Reflective Practice, ${ }^{27}$ hal ini dimungkinkan karena peran professional experience / pengalaman profesional yang berasal dari praktik dan penghayatan dalam kehidupan profesional yang diduga berpengaruh cukup kuat dalam membentuk persepsi para dosen.

Dengan menggunakan metode komprasi verbatim yang serupa, peneliti juga mencoba melakukan perbandingan antara konstuksi tema pada penelitian dengan beberapa standar internasional, diantaranya Physician Charter yang dikeluarkan oleh American Board of Internal Medicine (ABIM), Tomorrow's Doctor dari General Medical Council United Kingdom (GMC UK), CanMEDS 2015 oleh Royal College of Family Physician Canada, serta definisi profesionalisme dokter menurut AAMC (Association of American Medical Colleges). Hasil analisis menunjukkan beberapa irisan pengertian yang disajikan pada Tabel 3.

Dari analisisi yang telah dilakukan, ternyata didapatkan konstruksi tema yang tidak didapatkan pada Standar Internasional, yaitu komponen 'Penampilan' dan 'Spiritualitas'. Sementara itu, seluruh komponen rincian dalam 'Keterampilan Klinis' dan 'Pengetahuan' tercantum dalam Standar Nasional maupun Standar Internasional. Sementara itu, komponen 'Spiritualitas' hanya tercantum pada salah satu Standar Nasional yaitu SKDI. Pada Standar Internasional yang dikaji tidak didapatkan komponen 'Spiritualitas/religiusitas'. Sementara itu, komponen 'berpenampilan' tidak didapatkan pada Standar Nasional maupun Standar Internasional, maka komponen ini dipersepsikan secara mandiri oleh para informan. 
Tabel 3. Perbandingan komponen profesionalisme dalam penelitian dengan konstruk profesionalisme teoritik nasional maupun internasional

\begin{tabular}{|c|c|c|}
\hline & Standar & Komponen Profesionalisme \\
\hline \multirow[b]{2}{*}{ Standar Nasional } & SKDI & $\begin{array}{l}\text { Atiitude (Komunikasi, Spiritualitas, Etika); Kompetensi Klinis } \\
\text { (Terampil); Pengetahuan }\end{array}$ \\
\hline & KODEKI & $\begin{array}{l}\text { Attitude (Altruistis, Kasih sayang, Melihat pasien sebagi manusia, } \\
\text { Kerja sama dan kolegialitas, Tidak membedakan pasien); } \\
\text { Kompetensi Klinis (Bertindak sesuai standar profesi); Pengetahuan }\end{array}$ \\
\hline \multirow{4}{*}{$\begin{array}{l}\text { Standar } \\
\text { Internasional }\end{array}$} & Physician Charter & $\begin{array}{l}\text { Atiitude (Menghargai otonomi pasien, Altruistis, Dedikasi, Tidak } \\
\text { materialistis, Tidak membedakan pasien, Komunikasi); Kompetensi } \\
\text { Klinis (Terampil, Mampu bekerja di mana saja dan kapan saja); } \\
\text { Pengetahuan (Meningkatkan pengetahuan, Berinovasi) }\end{array}$ \\
\hline & Tomorrow's Doctor & $\begin{array}{l}\text { Pengetahuan; Kompetensi Klinis (Terampil); Attitude (Altruistis, } \\
\text { Dedikasi, Komunikasi, Kerja sama dan kolegialitas, Etika) }\end{array}$ \\
\hline & CanMEDS 2015 & $\begin{array}{l}\text { Attitude (Altruistis, Kasih sayang, Etika, Tidak membedakan pasien, } \\
\text { Dedikasi, Tidak materialistis, Kolegialitas); Kompetensi Klinis } \\
\text { (Bertindak sesuai standar profesi, Terampil); Pengetahuan }\end{array}$ \\
\hline & AAMC & $\begin{array}{l}\text { Attitude (Altruistis, Kasih sayang, Empati, Etika, Bertanggung } \\
\text { jawab, Tidak materialistis, Dedikasi, Kerja sama dan kolegialitas, } \\
\text { Tidak membedakan pasien); Pengetahuan (Meningkatkan ilmu } \\
\text { pengetahuan) }\end{array}$ \\
\hline
\end{tabular}

Spiritualitas telah dianggap penting dalam Ilmu Keperawatan di Indonesia. Aspek spiritual merupakan bagian integral dan interaksi perawat dengan pasien. Dalam hal ini perawat berupaya memenuhi kebutuhan spiritual pasien, meskipun agama yang dianut oleh perawat berbeda dengan pasiennya. ${ }^{28}$ Negara Indonesia berasaskan "Ketuhanan Yang Maha Esa", maka dari itu negara menempatkan agama dan kepercayaan sebagai spirit ketuhanan negara. ${ }^{29}$ Oleh karena itulah komponen spiritualitas dianggap penting di negara Indonesia, termasuk dalam hal profesi dokter.

Komponen berpenampilan/berbusana dipersepsikan sendiri oleh para dosen di FKUB. Seorang dokter diharapkan mampu berpakaian formal yang pantas. Pakaian formal dapat memengaruhi tingkat kepercayaan pasien terhadap dokter, serta kepercayaan diri dokter tersebut. ${ }^{20,30}$ Penulis mengidentifikasi bahkan aspek penampilan berbusana ini bahkan telah diangkat menjadi norma formal dalam proses pendidikan dalam bentuk peraturan akademik institusi, tidak hanya di institusi tempat dilakukan penelitian ini, namun juga di beberapa institusi pendidikan dokter dan kesehatan di Indonesia. Hal ini dapat dimaknai bahwa aspek berpakaian merupakan bagian yang dipandang penting baik sebagai upaya untuk membentuk profesionalisme maupun sebagai bentuk capaian dari pembelajaran/penghayatan profesionalisme itu sendiri. Meskipun peneliti belum mendapatkan hasil penelitian di Indonesia, namun peran medical-attire dalam menumbuhkan kepercayaan dan tingkat kepuasan pasien telah banyak dilakukan di luar negeri. . $^{20,30-32}$

Komponen-komponen profesionalisme dalam penelitian ini merupakan persepsi para dosen di FKUB yang dipengaruhi oleh pengalaman serta pengetahuan. Pengetahuan dosen berasal dari Standar Nasional yang wajib dipahami dan diterapkan oleh seluruh dokter di Indonesia, tidak hanya di FKUB saja. Oleh karena itulah muncul dugaan bahwa para dosen FK di universitas yang lain di Indonesia juga memiliki persepsi yang sama dalam memaknai profesionalisme dengan para dosen di FKUB. Dengan kata lain, konsep profesionalisme dalam penelitian ini diperkirakan dapat menjadi suatu konsep ke-Indonesia-an yang menjadi bentuk kearifan lokal di Indonesia. Selain menjadi kearifan lokal di FKUB, konsep profesionalisme dalam penelitian ini memperkuat temuan dari penelitian 
sebelumnya yang dilakukan oleh Kusumawati dkk, ${ }^{33}$ bahwa di dalam pembelajaran profesionalisme di Indonesia memiliki konstruk unik yang berasal dari akar budaya dan tata nilai bangsa Indonesia dan memberikan ciri pembeda dari bangsa lain..$^{33}$ Dua diantara komponen profesionalisme lokal, yang dikuatkan dalam penelitian ini adalah spiritualitas yang berasal dari religiusitas dan penampilan busana dokter (medical attire).

\section{KESIMPULAN}

Berdasarkan penelitian yang dilakukan pada 15 dosen di FKUB didapatkan kesimpulan bahwa komponen profesionalisme yang berhasil digali terdiri atas 3 komponen utama, yaitu: attitude, kompetensi klinis, dan pengetahuan. Ketiga komponen utama tersebut tercantum pada Standar Nasional dan Standar Internasional yang terkait profesionalisme. Namun, tidak semua komponen rincian profesionalisme tercantum pada Standar Nasional dan Standar Internasional. Komponen rincian yang tidak tercantum pada Standar Internasional tetapi tercantum pada Standar Nasional adalah spiritualitas, sedangkan yang tidak tercantum pada keduanya adalah komponen penampilan.

\section{DAFTAR PUSTAKA}

1. KKI. Standar Kompetensi Dokter Indonesia. Jakarta: KKI; 2012.

2. Walsh C, Abelson HT. Medical Professionalism. Perspect Biol Med. 2008;51(4):554-564.

3. Cruess RL, Cruess SR, Boudreau JD, Snell L, Steinert Y. Reframing Medical Education to Support Professional Identity Formation. Acad Med. 2014;89(11):1446-1451. doi:10.1097/ ACM.00000000000000427.

4. Wilson I, Cowin LS, Johnson M, Young $\mathrm{H}$. Professional identity in medical students: pedagogical challenges to medical education. Teach Learn Med. 2013;25(4):369-373. doi:10.1080/1040 1334.2013.827968.

5. Monrouxe L V. Identity, Identification and Medical Education: why should we care? Med Educ. 2010;44(1):40-49. doi:10.1111/j.13652923.2009.03440.x.

6. Program Studi Pendidikan Dokter. Pedoman Akademik Pendidikan Dokter Fakultas Kedokteran
Universitas Brawijaya. Fakultas Kedokteran Universitas Brawijaya; 2014.

7. FrenkJ,ChenL, BhuttaZA, etal.Health professionals for a new century: transforming education to strengthen health systems in an interdependent world. Lancet. 2010;376(9756):1923-1958. doi:doi:10.1016/S0140-6736(10)61854-5.

8. Birden H, Glass N, Wilson I, Harrison M, Usherwood T, Nass D. Teaching Professionalism in medical education: a Best Evidence Medical Education (BEME) systematic review. BEME Guide No.25. Med Teach. 2013;35(7):e1252-e1266. doi:http:// dx.doi.org/10.3109/0142159X.2013.789132.

9. Ng S, Lingard L, Kennedy TJ. Qualitative Research in Medical Education: Methodologies and Methods. In: Swanwick T, ed. Understanding Medical Education: Evidence, Theory and Practice. Vol 2nd ed. London: Wiley Blackwell; 2014:373.

10. Thornberg R, Charmaz K. Grounded Theory and Theoretical Coding. In: Flick U, ed. The SAGE Handbook of Qualitative Data Analysis. Vol London: SAGE Publications; :153-169.

11. Varpio L, Ajjawi R, Monrouxe L V, Brien BCO, Rees CE. Shedding the cobra effect : problematising thematic emergence, triangulation, saturation and member checking. Med Educ. 2017;51:40-50. doi:10.1111/medu.13124.

12. Eagly AH, Chaiken S. Attitude, Structure and Function. In: Hanbook of Social Psychology 4th Ed. Vol ; 1998:269-322.

13. Rosenberg MJ, Hovland CI. Cognitive, Affective and Behavioral Components of Attitude. In: Rosenberg MJ, Hovland CI, eds. Attitude Organization and Change: An Analysis of Consistency Among Attitude Components. Vol New Haven: Yale University Press; 1960.

14. Hirsch EM. The role of empathy in medicine: a medical student's perspective. AMA J Ethics. 2007;6:423-427.

15. Jain V. 3D model of attitude. Int J Adv Res Manag Soc Sci. 2014;3(3):5-7.

16. Puchalski CM. Spirituality and Health: The Art of Compassionate Medicine. Vol March. 2001.

17. Steinberg D. Altruism in medicine: its definition, nature, and dilemmas. Int $J$ Healthe Ethics Committees. 2010;19(2):249-257.

18. American Board of Internal Medicine. Medical professionalism in the new millennium: a physician charter. Ann Intern Med. 2002;136:243-246.

19. Pengurus Besar Ikatan Dokter Indonesia. Kode Etik Kedokteran Indonesia. Jakarta: PB IDI; 2012. 
20. Rehman SU, Nietert PJ, Cope DW, Kilpatrick A-O. What to wear today? Effect of doctor's attire on the trust and confidence of patients. Am J Med. 2005;118:1279-1286.

21. Hellstrom $\mathrm{O}$. The importance of a holistic concept of healthcare. Examples from the clinic. Theor Med. 1993;14(4):325-342. https://link.springer.com/ article/10.1007/BF00996340.

22. Wade DT. Holistic Health Care: What Is It, and How Can We Achieve It? Oxford: Oxford Centre of Enablement; 2009. https://pdfs.semanticscholar. org/80af/edfca2ffe3c96054aac6a85cf940a9c63a56. pdf.

23. Harris J. "Altruism: Should it be included as an attribute of medical professionalism?" Heal Prof Educ. 2017. doi:http://dx.doi.org/10.1016/j. hpe.2017.02.005

24. Merchant AB. Improving the ethics of medical practice: a family physician's viewpoint. Indian J Med Ethics. 2002;10(2).

25. Hojat M, Veloski J, Nasca TJ, Erdmann JB, Gonella JS. Assessing physician' orientation toward lifelong learning. J Gen Intern Med. 2006;21(9):931-936.

26. Cassam Q. Knowledge, Perception and Analysis. South African J Philos. 2008;27(3):36.

27. Lave J, Wenger E. Situated Learning: Legitimate Peripheral Participation. Cambridge: Cambridge University Press; 1991.
28. Rahmat I. Aspek Spiritual Dalam Keperawatan. Yogyakarta; 2002.

29. Budiyono. Hubungan Negara dan Agama dalam Negara Pancasila. Fiat Justisia J Ilmu Huk. 2014;8(3):410-423.

30. Houston WJ, Carek SM. Patients' Preference for Physician Attire: A Survey of Patients in Family Medicine Training Practice. Fam Med.43AD;9(643647).

31. Petrilli CM, Mack M, Petrilli JJ, Hickner A, Saint S, Chopra V. Understanding the role of physician attire on patient perceptions : a systematic review of the literature - targeting attire to improve likelihood of rapport ( TAILOR ) investigators. BMJ Open. 2015;5(e006578):1-18. doi:10.1136/ bmjopen-2014-006578.

32. Bearman G, Bryant K, Leekha S, et al. Healthcare Personnel Attire in Non-Operating-Room Settings. Infect Control Hosp Epidemiol. 2014;35(2):107-121. doi:10.1086/675066.

33. Kusumawati W, Prihatiningsih TS, Rahayu GR, Sastrowijoto S. Identification of Professional Behavior Attributes for Indonesian Medical Education. South East J Med Educ. 2015;9(1):19-25. 